\title{
Application of the geodiversity index for the assessment of geodiversity in urban areas: an example of the Belgrade city area, Serbia
}

\author{
Marina M. Ilić ${ }^{1, *}$, Sanja Stojković ${ }^{2}$, Ljupko Rundić ${ }^{3}$, Jelena Ćalić ${ }^{4}$ and Dejan Sandić 2 \\ ${ }^{1}$ PhD student,University of Belgrade, Studenski trg 1, Belgrade, Serbia; (corresponding author: mrnilic@yahoo.com) \\ 2 University of Belgrade, Faculty of Geography, Studenski trg 3/3, Belgrade, Serbia \\ ${ }^{3}$ University of Belgrade, Faculty of Mining and Geology, Đušina 7, Belgrade, Serbia \\ ${ }^{4}$ Geographical Institute „Jovan Cvijić” of the Serbian Academy of Sciences and Arts, Đure Jakšića 9, Belgrade, Serbia
}

doi: $10.4154 / g c .2016 .27$

Article history:

Manuscript received February 05, 2016 Revised manuscript accepted August 03, 2016 Available online October 07, 2016

\begin{abstract}
Considering the fact that urbanization is one of the most serious threats to geodiversity, it is important that this issue is taken into account in spatial development plans and georesource management strategies in urban areas. This paper presents the application of a geodiversity evaluation method by using the geodiversity index, based on the quantity of abiotic elements and relief roughness within a spatial unit. Geodiversity assessment, usually used for remote, protected and sparsely populated natural areas, is now carried out in an urban environment - the city of Belgrade, capital of Serbia, with a population of about 1.7 million inhabitants and very strong urbanization in the last few decades. The area of $3227 \mathrm{~km}^{2}$ is processed with the spatial resolution of $1 \times 1 \mathrm{~km}$. The acquired results from the geodiversity index are analyzed in the context of sustainable use of georesources and the threats to which geodiversity is exposed due to the territorial expansion of the city. The mapping of specific categories of geodiversity on the basis of quantitative assessment with the use of Geographic Information Systems can help decision makers and managers to take further steps that would reduce threats and protect the natural value of Belgrade.
\end{abstract}

elements, such as anthropogenic soils, ditches, underground facilities, etc., as well as archaeological sites, collections of minerals and rocks, and stones used for the construction of buildings and monuments.

According to GRAY (2004), geodiversity is particularly threatened by the development of urbanization that does not take into account the natural characteristics of the area. The largest threats are construction works which include the removal of surface layers and mixing them with construction material. The removal of surface soil disrupts the natural spatial forms and their characteristics, revealing barren bedrock. Sediments, fossils and rocks may be lost; water quality is reduced. Urbanization causes anthropogenization (even total destruction) of individual elements of geological diversity and at the same time it leads to the formation of new anthropogenic elements of space that can be numerous and occupy a larger area than the natural ones. For example, changes in soil usage lead to changes in soil quality (physical, biological and nutritional changes in value), the loss of organic matter and a general reduction of pedodiversity. Anthropogenized soils disrupt the natural system through changes of erosion, biodiversity, pollution, and environmental sustainability (FANNING \& FANNING, 1989). Another great threat is the permanent covering of geodiversity elements with asphalt and concrete for construction purposes. Apart from the protection of an object itself, the management needs to protect specific aspects, which are of geological interest. Preserved geodiversity is a foundation of a healthy environment because it is a part of the natural mechanisms, representing the basis for a better quality of life.

The evaluation of geodiversity, its spatial distribution and threats, to which it is exposed, contribute to the sustainable manaents of geodiversity of urban areas also include anthropogenic 
gement of georesources. This means finding a balance between the exploitation of these resources and their protection from overuse and improper use. It implies the development of plans and strategies to protect georesources from negative anthropogenic influences, while also making plans to protect the population and material goods from the negative effects and consequences of various geological and other natural geohazards (earthquakes, landslides, floods, weather, etc.). A richer geodiversity contributes to more complex processes of cities development. If the geodiversity is in accordance with human needs, the development of the cities will be facilitated. To avoid conflicts, it is important to plan the development (spatial, economic, cultural...) and manage resources (natural and social) in a sustainable manner. One of the prerequisites of the appropriate planning and management is a scientifically based assessment of the value of geodiversity and its spatial distribution. The mapping of geodiversity ensures that the protective measures focus on the entire area and not just on the individual objects (PELLITERO et al., 2011). According to these authors, maps of geodiversity assessment would be used in spatial planning where the primary objective is the establishment of territorial zones, which should be managed based on their capacity. RUBAN (2010) considers that the descriptive version of geodiversity, which is often applied in assessing objects of geoheritage, is important for geoconservation, while for all levels of
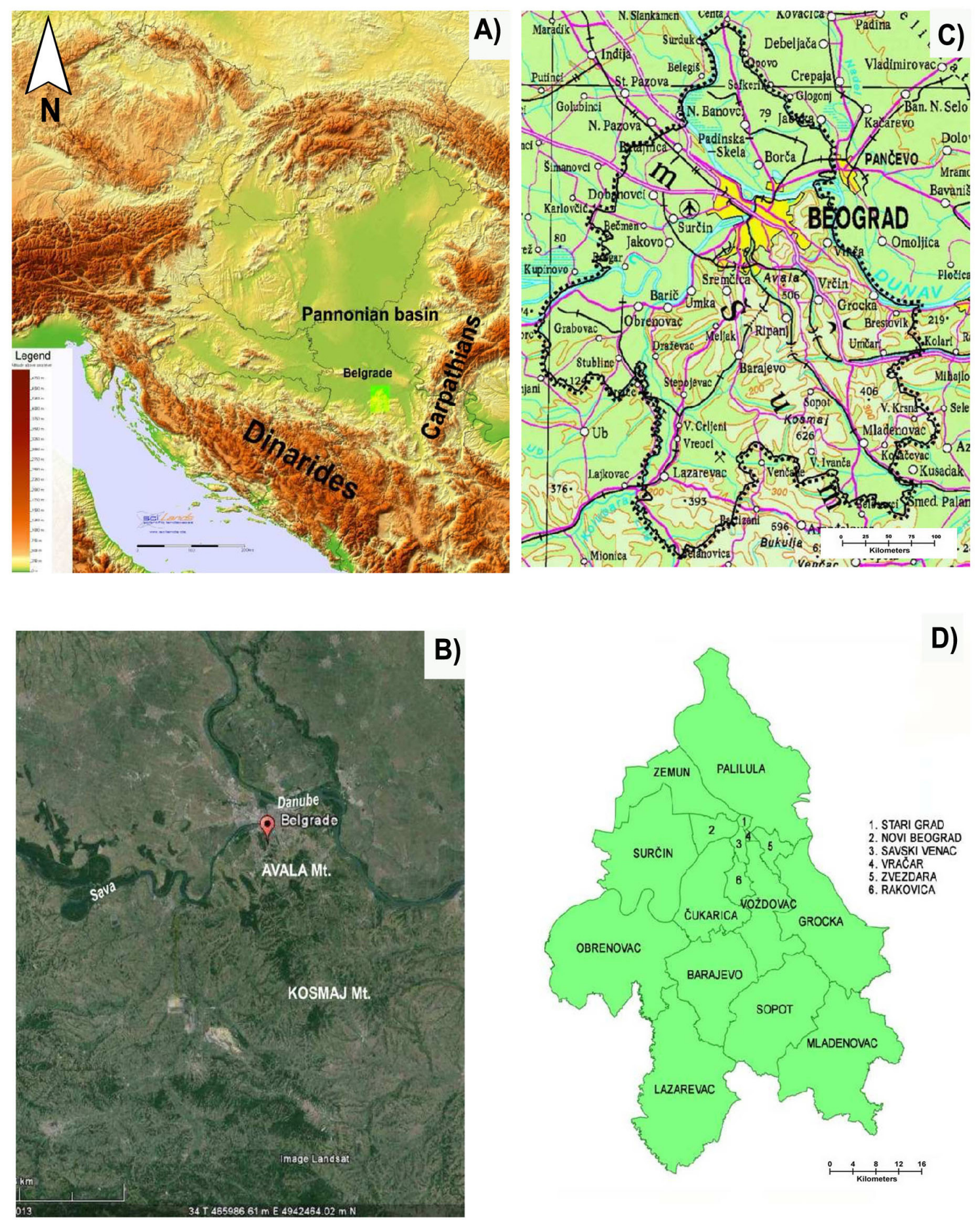

B)

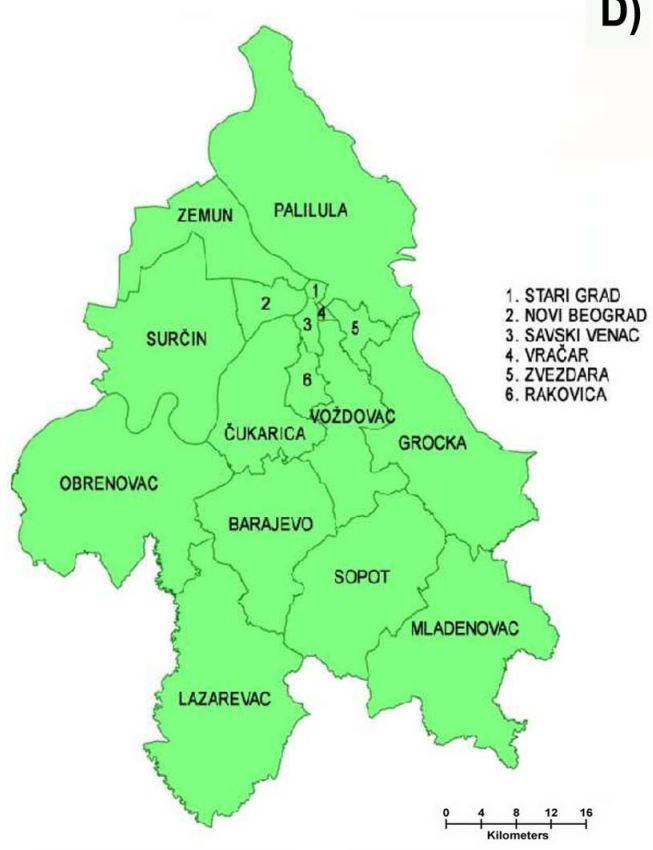

Figure 1. (A) Shaded hypsometric map (SCILANDS, 2015) and the position of Belgrade city area; (B) A satellite map of the studied area (GOOGLE EARTH, 2009); (C) Morphological and spatial (low land and hilly) map of the studied area (MILITARY GEOGRAPHICAL INSTITUTE, 1989); (D) The administrative division of the territory of the city of Belgrade. 
governance, a quantitative geodiversity assessment needs to be carried out. This paper presents one of the ways of quantifying the elements of geological diversity in an urban area, using the example of the Belgrade city area.

\section{STUDY AREA}

Belgrade, the capital of Serbia, is located in Southeast Europe, on the Balkan Peninsula, at the confluence of the Sava and the Danube Rivers (Fig. 1A, B). It covers an area of $3227 \mathrm{~km}^{2}$ of which almost $276.6 \mathrm{~km}^{2}$ includes rivers and riparian land. According to the 2011 Census (VUKMIROVIĆ, 2014), 1.639.121 inhabitants live in the territory of the City of Belgrade, giving a population density of 508 inhabitants per $\mathrm{km}^{2}$. Belgrade accounts for over $3.6 \%$ of the territory of the Republic of Serbia, and is home to over $20 \%$ of the total Serbian population. The territory is administratively divided into 17 municipalities (Fig. 1D).

From a geotectonic point of view, the Belgrade city area includes the southern margin of the Pannonian Basin, northern parts of the Vardar Zone and the Serbo-Macedonian Massif(MAROVIĆ et al., 2007). Morphologically, two distinct units are clearly recognized: a) the southern part of the Pannonian Plain that represents vast plain and low land area located north of the Sava and Danube rivers, and b) a mountainous/hilly area (Mts. Šmadija, Avala and Kosmaj) located south of the Sava and Danube rivers (Fig.1C). The primary morphological relief of the Belgrade city area results from the tectonic movements that occurred during the Palaeogene and early Neogene. During the OligoceneMiocene, a few horsts (Mt. Avala, Mt. Kosmaj) and a large-scale tectonic basin (Pannonian Basin) were created, as well as small tectonic depressions south of the Pannonian Basin (MENKOVIĆ et al., 2013; MAROVIĆ et al., 2007). The turbulent tectonic activity was accompanied by volcanism, which lasted until the end of the Miocene. Volcanic landforms created during this period are not preserved in the territory of Belgrade, instead igneous rocks from that period (Mt. Avala, Mt. Kosmaj) and pyroclastic material can be observed.

The traces of the complex and turbulent geological history can be analyzed based on various indicators. The oldest known rocks in the territory of Belgrade belong to the Devonian-Carboniferous age (DIMITRIJEVIĆ et al., 1985a,b; FILIPOVIĆ et al., 1980; PAVLOVIĆ et al., 1980; FILIPOVIĆ et al., 1978; DIMITRIJEVIĆ et al., 1975a,b). However, the geological structure of the hilly-mountainous area south of the Sava and the Danube rivers is much older and more complex than the structure of lowland terrain north of them. Aquatic and terrestrial phases alternated several times, leaving behind the traces that, depending on the age and later geomorphological processes, are more or less preserved. The first determined marine phase began in the Upper Jurassic, about 150 million years ago and lasted throughout the Cretaceous until about 65 million years ago (ANDJELKOVIĆ, 1989; DIMITRIJEVIĆ et al., 1985a,b; FILIPOVIĆ et al., 1980; PAVLOVIĆ et al., 1980; DIMITRIJEVIĆ et al., 1975a,b). During that time, the wider territory of the present Belgrade was completely covered by the Tethys Ocean. Based on poor geological evidence, throughout the Palaeogene, the Belgrade area was not covered by the sea, due to erosion or masking by subsequent transgressions. At the beginning of the Middle Miocene, about 15 million years ago, the Belgrade area was flooded by the Central Paratethys Sea (RUNDIĆ et al., 2013; RUNDIĆ, 2010). This palaeogeographic regime lasted more than 3 million years and occasionally there were a few connections to the world ocean. However, at the Middle/Upper Miocene boundary (ca.11.6 Ma), due to tectonic uplift of the Carpathian Mountains, the aforementioned seaways were broken. Thus, the isolated marine ecosystem, under the increasing influence and influx of freshwaters from the adjacent land, slowly turned into a large, long-lived lake - Lake Pannon (TER BORGH et al., 2013; RUNDIĆ et al., 2011). This was the largest aquatic system in central Europe, characterized by an endemic fauna. During the Upper Miocene-Pliocene, progradation processes and the considerable input of terrigenous materials led to successive infilling of this lake (RADIVOJEVIĆ et al., 2014). In place of the large lake, only smaller lakes and marshes remained. This area then finally dried out about 3.5 million years ago, when the continental phase started and which has continued to the present, (ANDJELKOVIĆ, 1989; DIMITRIJEVIĆ et al., 1985a,b; FILIPOVIĆ et al., 1980; PAVLOVIĆ et al., 1980; DIMITRIJEVIĆ et al., 1975a,b). Some authors consider that presently there are particular remnants of the marine-limnic morphology, although fluvial and hillslope relief dominates (MENKOVIĆ et al., 2013). The remaining ponds and lakes after the loss of the lake Pannon became part of the Danube river network. During the Pleistocene ice ages, the present Belgrade area was not glaciated, but the interchange of dry and wet periods affected the intensity of erosion. The most intense processes were fluvial, aeolian, hill-slope and karstic. During the Quaternary, neotectonic activity took place influencing the intensity of particularly the fluvial and hill-slope erosional processes.

Unlike the sediments from older geological periods deposited in marine conditions, Quaternary sediments (fluvial, lacustrine, aeolian, etc.) were deposited on land. The early and middle Pleistocene is represented by river and lake gravels and sands with the presence of Corbicula bivalve shells (RUNDIĆ, 2010). Loess formations, occurring in the form of loess plateaus (north of the Sava and Danube) and slope loess (south of the Sava and Danube) are characteristic of the Upper Pleistocene. Loess sediments were formed throughout the Pleistocene, in continental conditions, by sand and dust blown from the north over the existing geological units and landforms (RUNDIĆ, 2010; ANTONOVIĆ et al., 1978). During the Holocene, the youngest sediments of Belgrade are being formed, represented by alluvial deposits of the Sava and the Danube rivers, soils, hillslope sediments, etc. In hydrogeological terms, the territory of Belgrade is extremely complex (VRANJEŠ, 2012; FILIPOVIĆ, 2003, 2005; MILOJEVIĆ et al., 1971, 1975) and is divided into ten zones with corresponding sub-zones (VRANJEŠ, 2012).

In a pedogeographical sense, the territory of Belgrade includes two regions. The first pedogeographical area, north of the Sava and the Danube, is the steppe and forest-steppe region of the Pannonian Plain. The second pedogeographical area extends south of the Sava and the Danube rivers. In the Pannonian Plain, the alluvial deposits on river terraces host fluvisols, gleysol, chernozems, and solonchaks (IUSS WORKING GROUP WRB, 2006). There are also loess plateaus with chernozems and salt marshes soils. South of the Sava and the Danube, Neogene sediments prevail. Overlying the sediments, eutric cambiosols developed, which dominate in the sequence: regosol - leptosol (rendzinas) - eutric cambisol - luvisol while the heavy sediments predominately contain clays (vertisol). In the areas of significant soil erosion there are many colluvial soils, and on the lower river terraces there are fluvisols, fluvic cambiosols and gleysols. Within Belgrade specifically in the urban area, technosols are common, especially in the area north of the Sava and the Danube rivers, where intensive backfilling started after World War II. Novi Beograd was built on this terrain, and the low-intensity fill- 
ing continues today during almost all construction and infrastructure works. Soil fill is most often composed of a mixture of natural materials and construction waste.

Numerous occurrences of surface and groundwater that modify the relief of Belgrade are significant for geodiversity. Given that fluvial erosion has the greatest influence on the formation of relief in Belgrade, it is important to preserve and maintain the drainage network and watercourses. The hydrographic network of Belgrade consists of permanent and seasonal smaller river and stream flows that belong to the basins of the Sava, the Danube and the Velika Morava rivers. It is estimated that there are over 300 watercourses in the Belgrade area (DEDIĆ \& INĐIĆ, 1990). In addition to surface waters, the Belgrade area is characterized by a variety of groundwaters that occur at different depths depending on the geological composition, relief, sources, feedsand anthropogenic influences. The most abundant are the hills south of the Sava and Danube where groundwater sources of different yield, chemical composition and temperature occur. There are also occurrences of mineral and thermal waters (FILIPOVIĆ, 2003; FILIPOVIĆ et al., 1978; KOMATINA, 1976; MILOJEVIĆ et al., 1975; MILOJEVIĆ et al., 1971).

Geodiversity is greatly influenced by contemporary climatic conditions that affect the intensity and scale of erosion, but also those that prevailed in the geological past, especially during the Quaternary. At the beginning of the Quaternary (i.e. Pleistocene) cooling and the beginning of the Ice Age occurred, during which climatic conditions drastically changed. Pleistocene cooling on the territory of Belgrade was reflected through the shift between colder and drier with warmer and wetter phases. During the cold phases, there were intensive aeolian processes, while the fluvial processes subsided due to smaller amounts of surface water. In the warmer phases, aeolian processes were weaker, while the fluvial and karstic ones were more intense. The blowing of loess sediments during the Pleistocene was particularly intense in the
Pannonian Basin and somewhat weaker in the peripheral parts. During the Holocene, when it comes to warming and changes in climate conditions which existed in the Pleistocene, the climate was not stable, but there were fluctuations and changes. Today, Belgrade has a moderate continental climate (POPOVIĆ, 1990). As a result of urbanization due to the construction of settlements with high, densely packed buildings, street paving and the use of large amounts of concrete, the emergence of new sources of heat, and reduced vegetation cover, there is now the „town climate“ (POPOVIĆ, 1990).

\section{METHODOLOGY}

For the evaluation of geological diversity in this work the equation for the Geodiversity Index (Gd) evaluation (1), proposed by SERRANO \& RUIZ-FLAÑO (2007) was used:

$$
\mathrm{Gd}=\mathrm{Eg} \mathrm{R} / \mathrm{Ln} \mathrm{S}
$$

Where Gd - Geodiversity Index; Eg - Number of different abiotic elements in the spatial unit; $\mathrm{R}$ - coefficient of roughness of the spatial unit; $\mathrm{S}$ - Surface of the spatial unit $\left(\mathrm{m}^{2}\right) ; \mathrm{Ln}$ - natural logarithm.

In references that dealt with the quantitative assessment of geodiversity (MELELLI, 2014; SILVA et al., 2013, 2014; PELLITERO et al., 2011; HJORT \& LOUTO, 2010; SERRANO et al., 2009; SERRANO \& RUIZ-FLAÑO, 2007), the spatial units in respect of which the assessment of geodiversity elements was made, were different forms of landscape or geomorphological units, types of habitat or the pixels of different sizes (grid model). Due to terrain complexity, the uneven distribution of abiotic elements and a strong process of urbanization, the Gd in this paper were not done for natural units, but for the entire administrative territory of the city of Belgrade. It was divided into pixels sized 200x200 m and 1000x1000 m. Pixel sizes were determined based

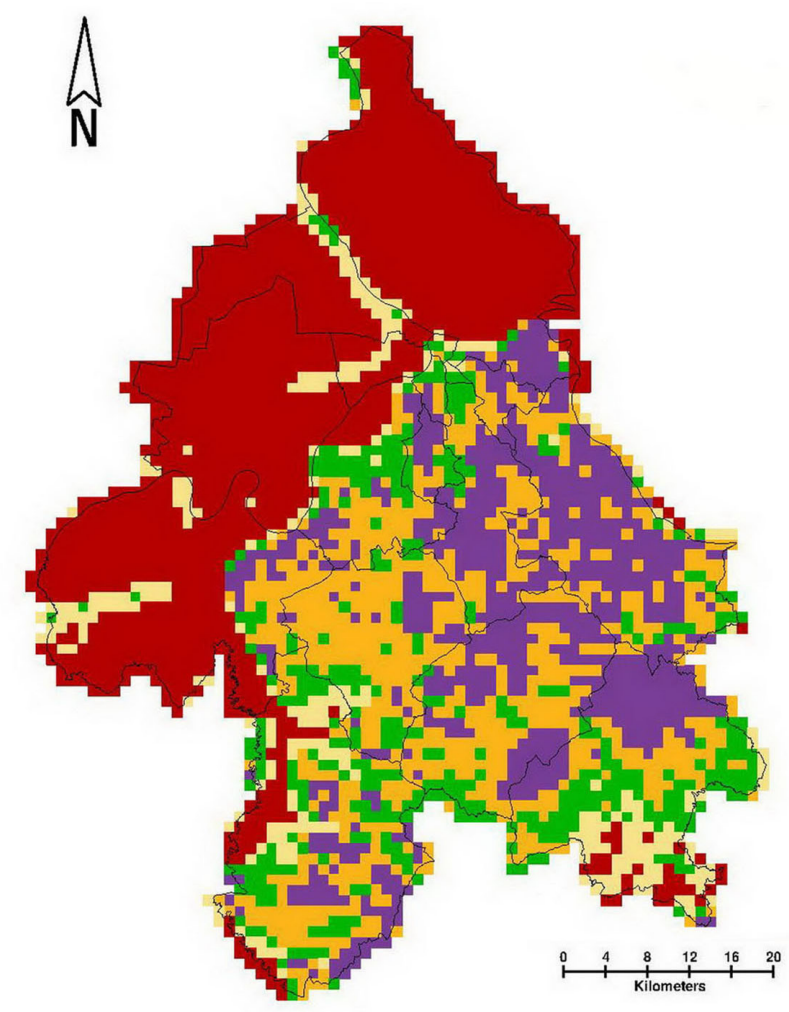

Legend

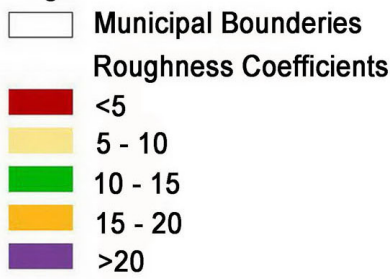

Figure 2. Map of relief roughness of Belgrade city area. 
on the size of the territory and the scale of input data (HJORT \& LOUTO, 2010; HENGL, 2006). After the analysis and calculations for both networks, it was found that the network 1000x1000 $\mathrm{m}$ is more suitable for the mapping and assessment of geodiversity for the whole territory of the city.

For data analysis and the clearer presentation of the obtained spatial results, a Geographic information system (GIS) was used. This involved creation of the geodatabase from which records provided the information necessary for the assessment of geodiversity and its spatial distribution. In this study, we used an entity model that assumes that the phenomena in the real world can be clearly identified in the form of their attributes and spatial position. The main sources of geographical data were geological, geomorphological, pedological and hydrological maps of the territory of Belgrade (scale 1:50K, 1:100K and 1:300K), data from the available published literature and data collected in the field. For entering, editing, analysis and creation of vector spatial data GIS software package GeoMedia Professional 6.3 by the Intergraph Corporation was used. To process rasters, the software package Idrisi Andes ${ }^{\mathrm{TM}}$ was used.

In order to obtain the coefficient of relief roughness of the spatial unit, the calculation represented in ĆALIĆ et al. (2012a, $2012 \mathrm{~b}$ ) was used. The authors obtained the roughness coefficients for northern Serbia using the geomorphometrical analysis in Idrisi Andes ${ }^{\mathrm{TM}}$ software package. The input data for the digital terrain model were taken from the SRTM database, with 90 m resolution (USGS, 2011). This resolution was subsequently resampled from $90 \mathrm{~m}$ to $200 \mathrm{~m}$. The grid cells were grouped into $5 \times 5$ moving windows in order to obtain the average elevation within each window. Each cell was first assigned a value representing its elevation difference from the average elevation within a window. The standard deviation of all differences within a moving window was assigned to the central cell, and this standard deviation value was treated as a roughness coefficient of the central cell. In this way, the standard deviation (i.e. roughness coefficient) illustrates the cell's relation to its immediate surroundings. For the purposes of the present study of geodiversity index, the 200x200 $\mathrm{m}$ resolution was resampled to $1000 \times 1000 \mathrm{~m}$ resolution (Fig. 2).

Due to the size of the territory and the scale of the input data, the assessment of geodiversity was made at the level of elements: geological (lithological-stratigraphic), geomorphological (morphogenetic), pedological (basic soil types) and hydrological (rivers, springs). The assessment did not include the level of regions (rifts, neotectonic depressions) and micro level (minerals, fossils). Also, the assessment did not include petrographic elements that are used for the construction of buildings and monuments as well as geoarchaeological elements.

\section{RESULTS AND DISCUSSION}

From various input data for the purposes of calculating the number of different abiotic elements, new maps were formed: a simplified geological map (Fig. 3), morphogenetic map (Fig. 4), map of soil types (Fig. 5) and map of rivers and springs (Fig. 6). In creating the geological-stratigraphic map, the Basic geological map of Serbia 1:100000 - sheets Beograd (DIMITRIJEVIĆ et al., 1985a,b), Pančevo (DIMITRIJEVIĆ et al., 1975a,b), Smederevo (PAVLOVIĆ et al., 1980), Obrenovac (FILIPOVIĆ et al., 1980), Gornji Milanovac (FILIPOVIĆ et al., 1978; Vladimirci (FILIPOVIĆ et al., 1967) and data from both the literature and from the field were used. The data were simplified and grouped in different stratigraphic units (Fig. 3). The rocks that are particularly specific and that further affect the variety of geodiversity (phonolite and serpentinized peridotites) were placed in a separate category. To create a morphogenetic map (Fig. 4), the data from the Geomorphological map of Serbia 1:300000 (MENKOVIĆ et al., 2013) as well asfield observations were used. Due to the map scale, individual terrain elements and features were not plotted. Instead, areas with predominant morphological proces-
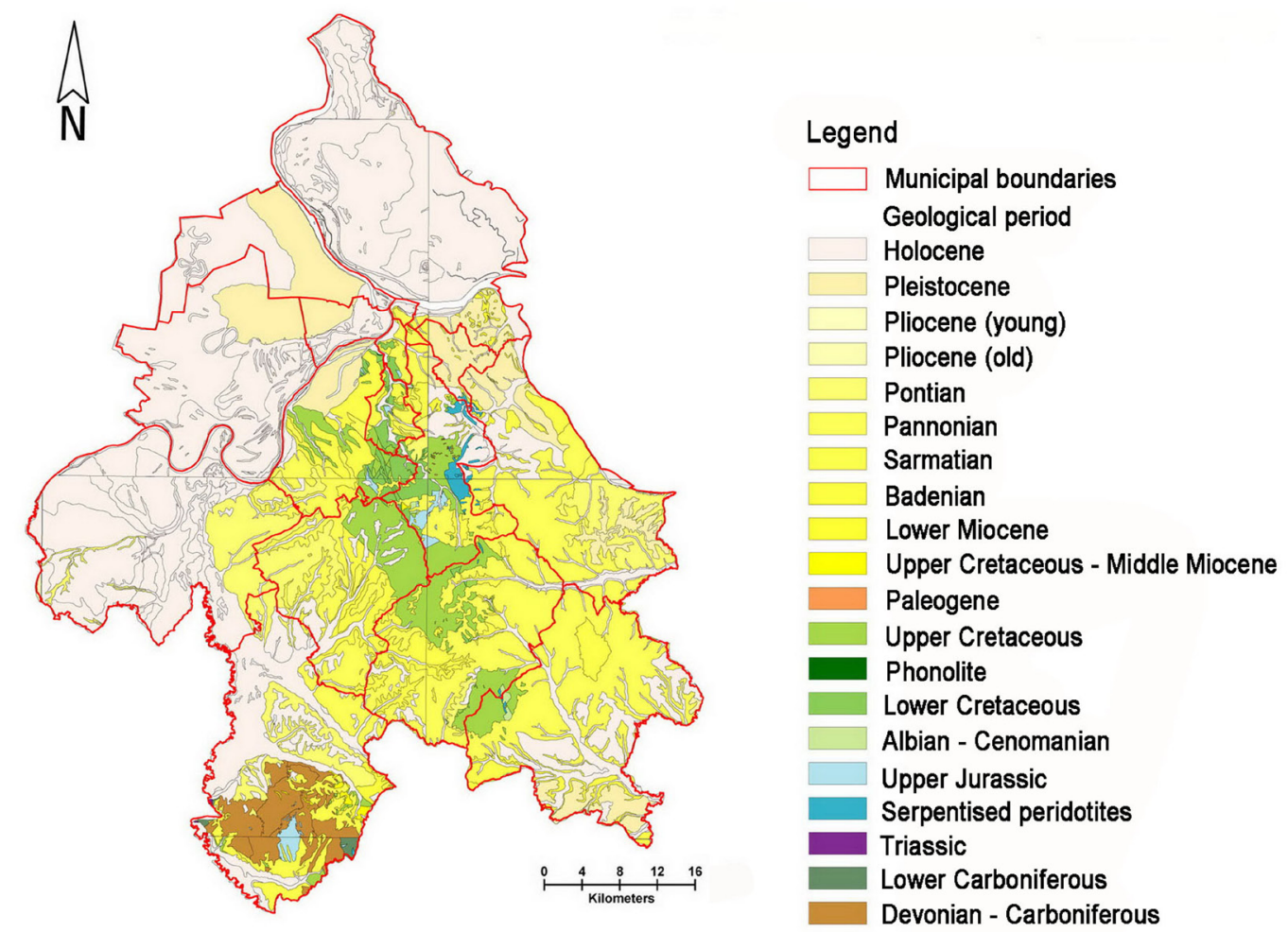

Figure 3. A simplified geological map of Belgrade city area. 


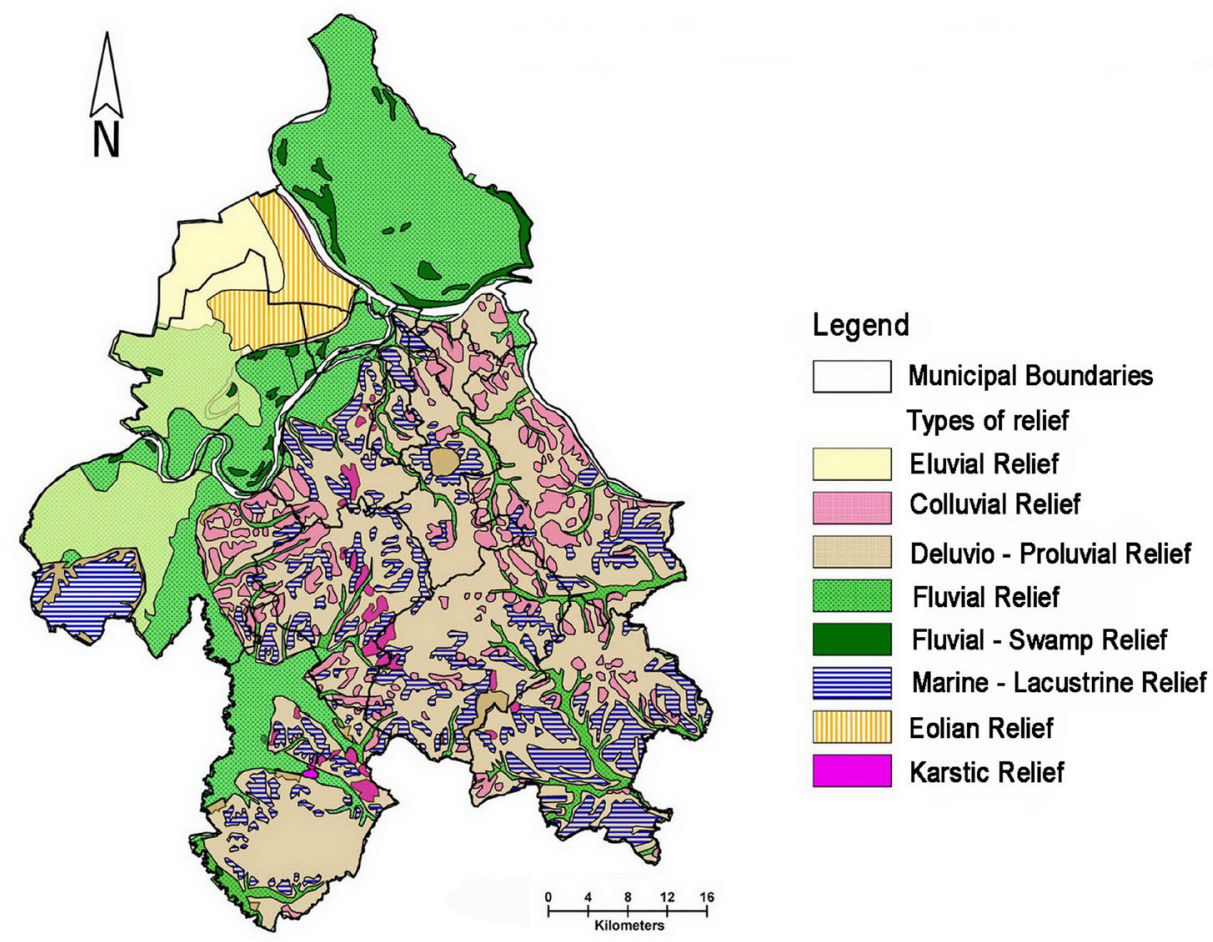

Figure 4. The morphogenetic map of Belgrade city area.

ses and typical landforms were shown. The basis for creating the map of soil types (Fig. 5) was the analogous Basic pedological map of Serbia 1:50000- sheets Beograd 1,2,3,4; Arandjelovac 1,2; Obrenovac 2,4; Zrenjanin 3,4; Požarevac 3 (INSTITUTE OF SOIL RESEARCH, 1963). Data were digitized and types of soilare harmonized with the FAO classification (IUSS WORKING GROUP WRB, 2006). To calculate hydrographic elements, the map of rivers and springs was created (Fig. 6). The sources were the analogue Map of water objects 1:50000 - sheets Beograd
1,2,3,4; Kragujevac 1,2; Lazarevac 1,2; Smederevo 1,3,4 and Zrenjanin 4 (FEDERAL SECRETARIAT FOR NATIONAL DEFENCE \& THE FEDERAL COMMITTEE FOR AGRICULTURE, 1988) and the analogue Topographic map 1: 300000 - sheets Beograd and Kragujevac (MILITARY GEOGRAPHICAL INSTITUTE, 1988).

Geological, geomorphological, pedological and hydrological elements of geodiversity were quantified (Fig. 7) in order to obtain a Gd value for each pixel (size 1000x1000 m). The final re-

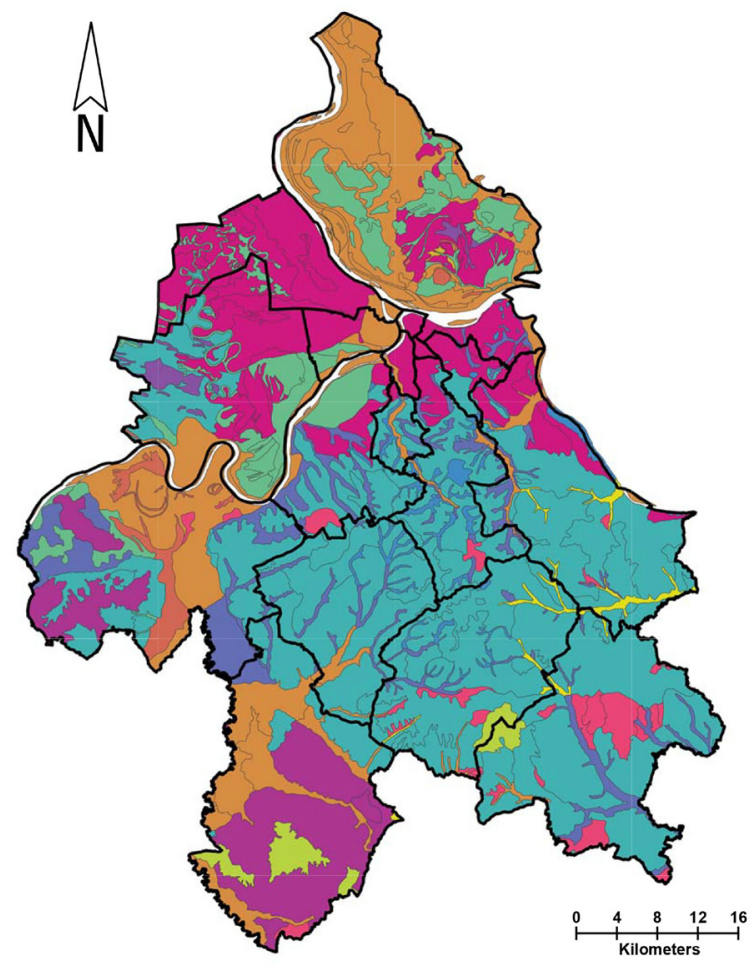

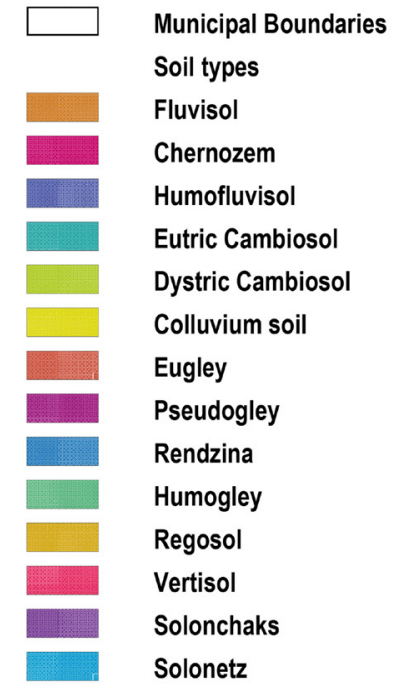

Figure 5. The map of soil types in the studied area. 


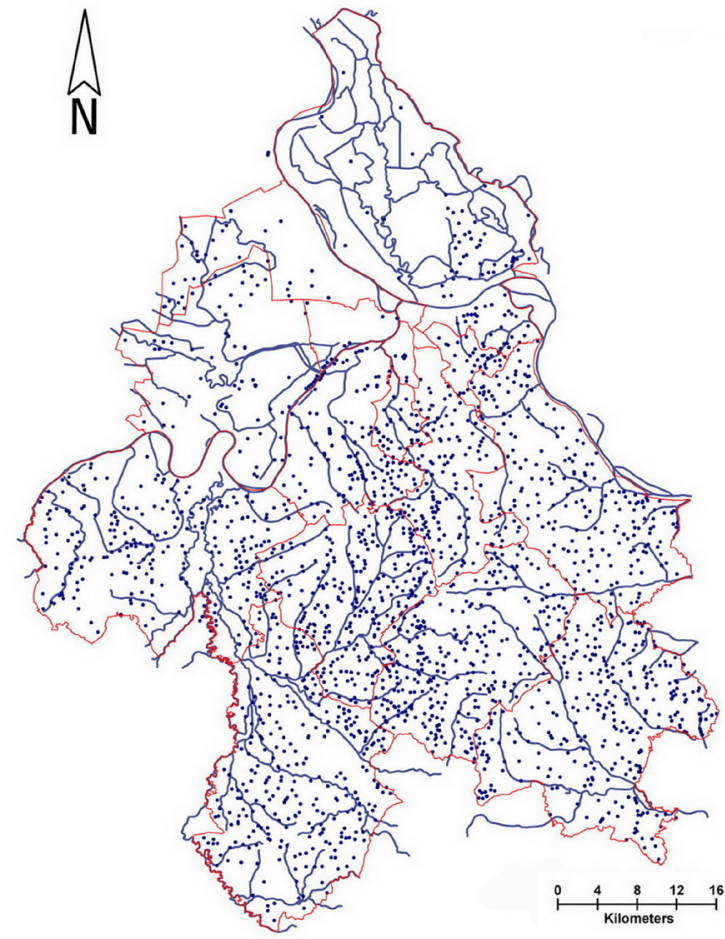

\author{
Legend \\ Municipal Boundaries \\ Springs \\ Rivers
}

Figure 6. The map of rivers and springs in the studied area.

sults were classified into five categories $(<5$ very low, 5-10 low, 10-20 medium, 20-30 high, $>30$ very high (Fig. 8).

The results showed that ,greater rugosity implies greater geodiversity“ (PELLITERO et al., 2011; SERRANO \& RUIZFLAÑO 2009), which in the case of Belgrade means that the Gd is low in the Pannonian Plain area (ĆALIĆ et al., 2012a, 2012b) and increases with the increase of roughness coefficient. The reason for the very low Gd value in the Pannonian Plain is primarily low altitude but also the homogeneity of rocks and soil in which aggradation is dominant fluvial process. Thanks to the climatic characteristics in these areas, the Gd value is slightly higher in places showing development of aeolian relief forms and areas of major watercourses. Low Gd is characteristic of areas where the coefficient of roughness (R) is between 10-20, forest soil and pseudo-gley dominate, and the rocks of different ages are present. The mean value of Gd includes more than $1 / 4$ of the studied area and it is represented in the territory where $\mathrm{R}$ is greater than 20 , and geological and soil composition are more heterogeneous. Increased relief roughness intensified geomorphological processes, which led to the creation of diverse landforms. High and very high Gd covers $2.6 \%$ of the territory of Belgrade, and is represented not only in the areas with the highest coefficient of terrain roughness (the mountains Avala and Kosmaj), but also in the areas where specific geological structure and intensive geomorphological processes (the valley of the Topčider River, the valley of Vrčin River) occur. Very high Gd is present in areas of serpentinized peridotites and the rocks of the Upper Jurassic and Upper Cretaceous and high Gd is encountered in areas of rocks of different geological age (Upper Jurassic, Badenian, Sarmatian, Pontian, Pleistocene, and Holocene).

Of the geomorphological processes present in the areas with the highest Gd, the most intense are hillslope and marine-limnic, while fluvial, colluvial and karst are of lower intensity. Soils with very high Gd are the rendzina, acidic brown soil, chernozem, brown forest soil, while Gd of the alluvial land is relatively small.
From the geoconservation point of view, it is very important that high Gd is found in the populated areas, which facilitates geoconservation activities. The great advantage is that a part of the areas where Gd is very high or high is already protected by the state as the Landscape of Outstanding Features (Avala, Kosmaj). In the valley of the Vrčin River, and Leštane where Gd is very high as well as in other areas with high $\mathrm{Gd}$, geoconservation activities have not yet been undertaken (in the areas of the municipality of Novi Beograd, Grocka, Lazarevac, Sopot, Obrenovac, Barajevo). The significant drawback is that the process of urbanization (the river is partly channeled and passes through the industrial zone) affects the valley of the Topčiderska Reka River.

Curiously, the areas with very high as well as areas with very low Gd are less populated to uninhabited (Fig. 9). Population is the most intense in the areas with small and medium values of Gd. Varied geodiversity is good in the context of geoconservation, preventing degradation, biodiversity protection, etc. However, in a functional sense, low Gd does not necessarily mean that these areas are „less important“. If we observe the example of Belgrade, the best land for agricultural production is represented in the areas with very low Gd. Thus, calculated geodiversity is most useful in the context of protecting the diversity of natural values and the development of commercial sectors that rely on this diversity. However, for industries such as agriculture or construction the social and economic value of geological diversity must also be taken into consideration.

Geodiversity has different levels of importance and value depending on whether it is represented in the town centre itself or in the wider environment, including the surrounding municipalities. In the very urban centre, its importance is related to the construction of buildings for housing and overhead and underground infrastructure facilities (water supply, rain and sewage systems, telecommunications and electrical installations, heating and gas pipelines, etc.), as well as for the disposal of municipal and industrial waste (NAZZAL et al., 2015, DAVIDSON et al., 

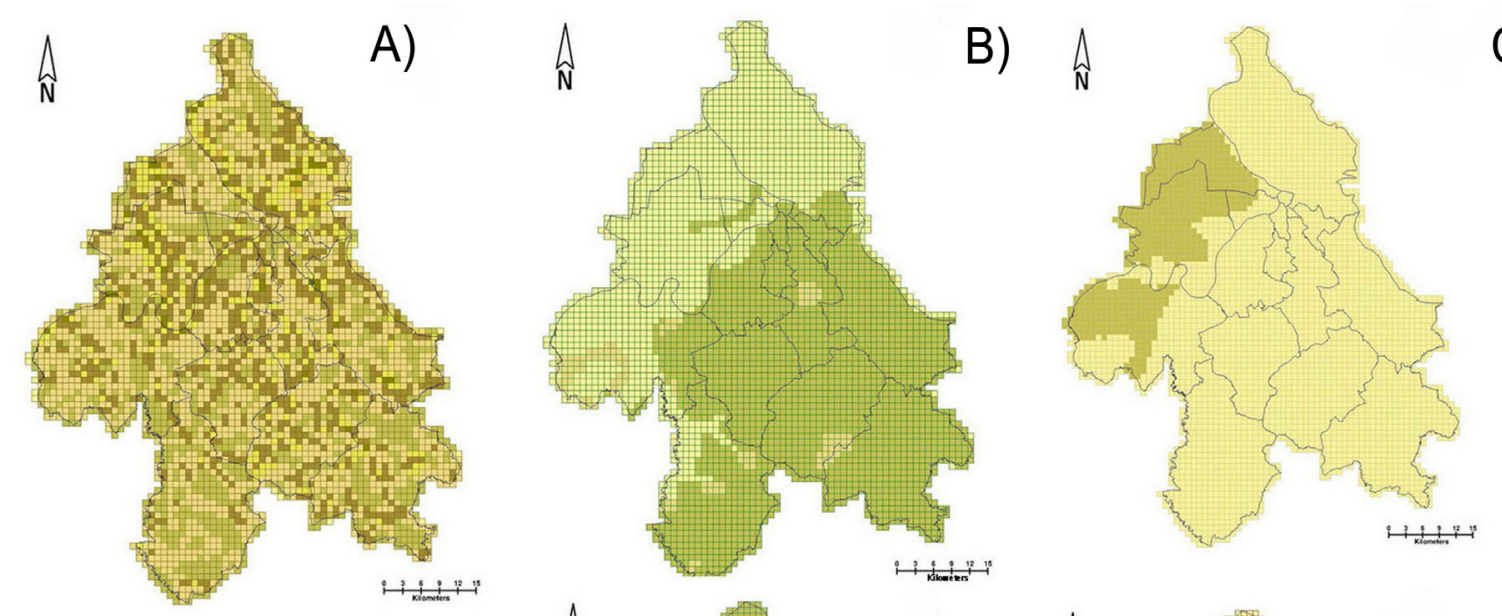

C)
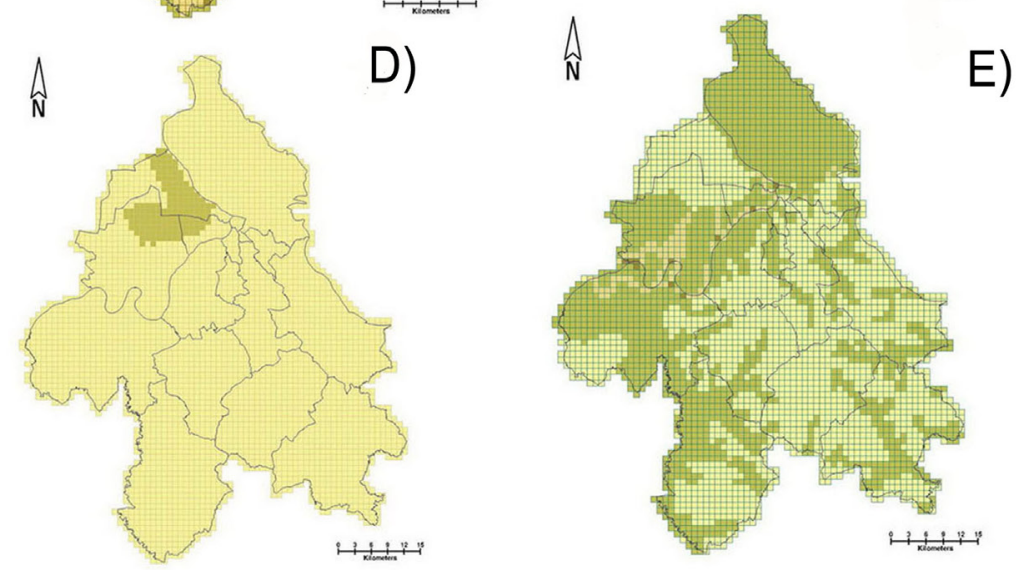

$\widehat{\Lambda}$

F)
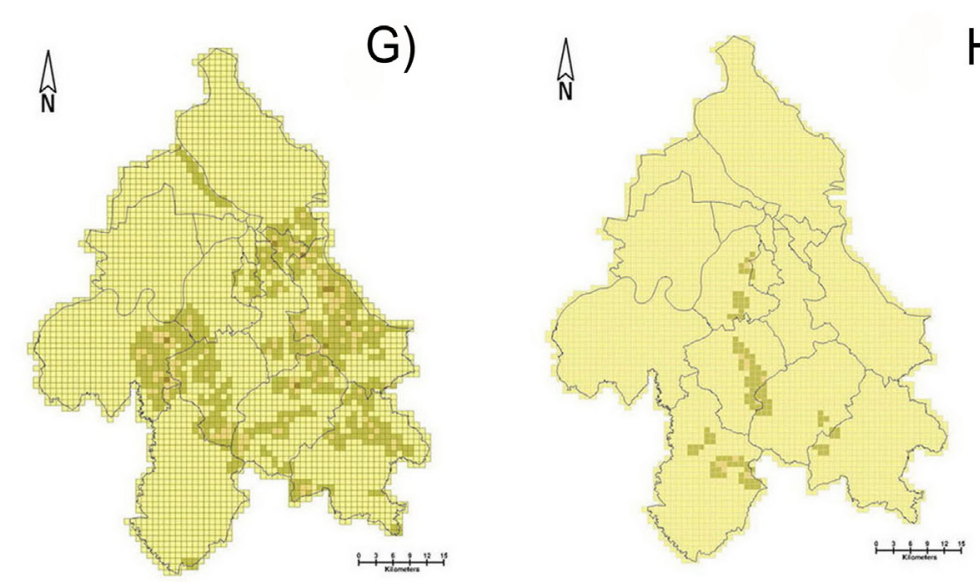

H)
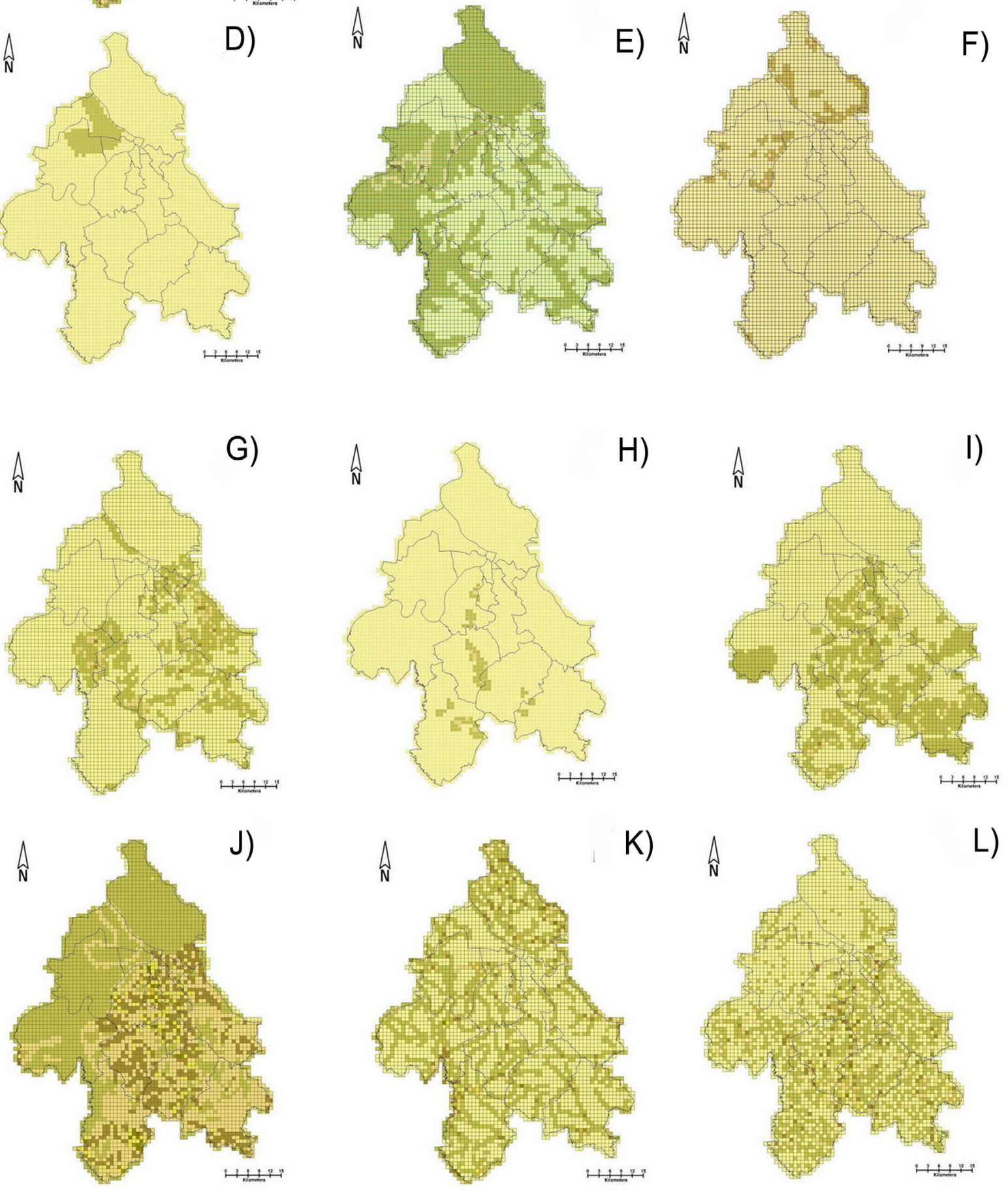

I)

L)

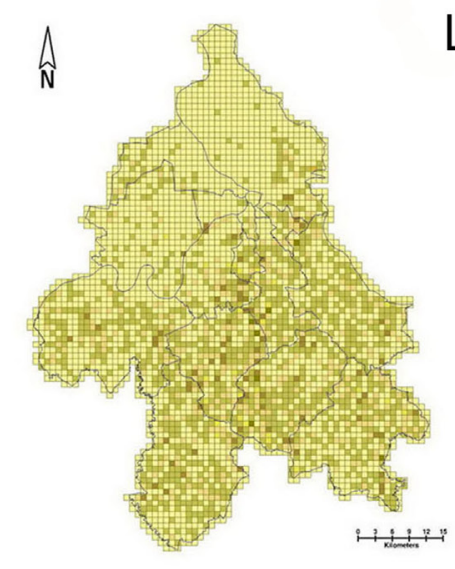

Figure 7. Number of different abiotic elements (Eg): A) Soil B) Deluvio-proluvial Relief C) Eluvial Relief D) Eolian Relief E) Fluvial relief F) Fluvio-swamp Relief G) Colluvial Relief H) Karstic Relief I) Marine-Lacustrine Relief J) Geology K) Rivers L) Springs. 


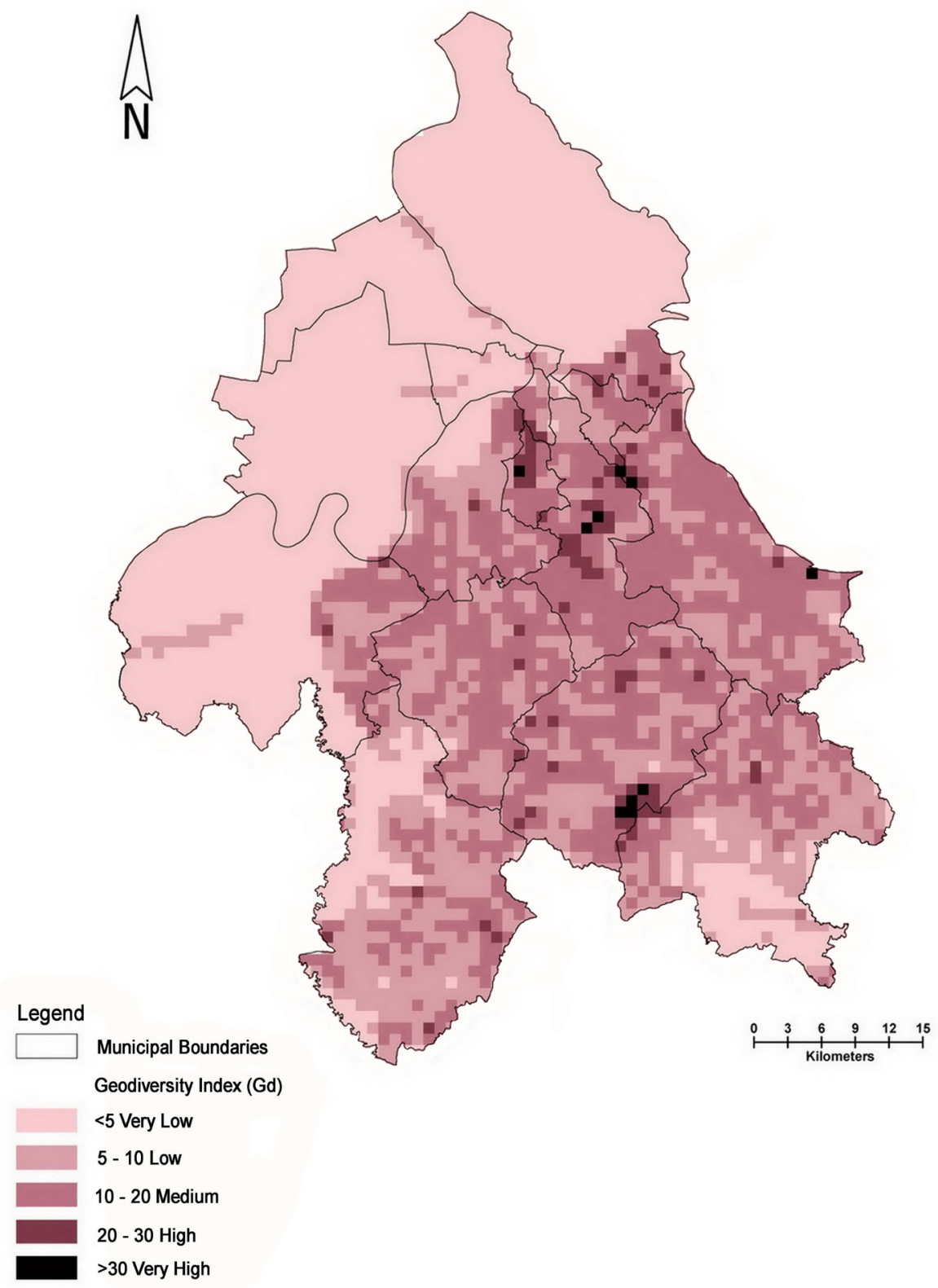

Figure 8. The geodiversity index map of the studied area.

2006). In suburban areas, which are partly urbanized, its significance is in the use of minerals (stone, clay, gravel, sand and other non-metals) and energy resources (lignite), food production (land), water supply (groundwater sources, geothermal sources), etc.

In urban areas, geomorphological objects are evaluated mainly based on the value they have for man. According to ERHARTIČ \& ZORN (2012) the relief forms become natural value only if they also contain a social component. Relief forms, particularly in urban areas, are the source of ecosystem services (geosystem services) that are fundamental for an environmentally sustainable economy and social development, through supplying the population with economic, scientific, cultural or other goods (KIERNAN, 2013). However, although they have great significance for the development of cities, during construction each shape that deviates from a flat one is considered unfavourable and its modification is planned. JARMAN (1994) notes: ,wherever the development starts there is a tendency to eliminate the characteristics of relief rather than incorporate it into local development plans". Also, in addition to destroying the existing relief, the evolution of new forms of anthropogenic (technogenic) relief is created. In spatial planning, the elements of the relief should be taken into account and the threats that can jeopardize its diversity and values must be reduced. GRAY (1997) notes that the intensity of factors that cause adverse effects depends on the ability of the landscape to absorb morphological changes.

When Belgrade was planned, little attention was paid to the relief, and most attention was paid to fit in and adapt the buildings to the Kalemegdan ridge and few thoughts were given to the territorial expansion of the city. Interestingly, the intense urbanization of Belgrade demanded adjusting and modifying the properties of the relief because of its inadequacy for the construction of housing infrastructure. The permanent loss of geodiversity is particularly evident in the exploitation of mineral resources in the active quarries and open pit mines of the Kolubara basin. Lignite mining has led to the destruction of fertile lands in the alluvial plain of the Kolubara River and its tributaries, and in their place barren soil of different materials has been piled up (CVETKOVIĆ et al., 2013; PRUVOT et al., 2006). In addition to the destruction of arable land, there was the destruction of the geological, geomorphological and hydrological elements of geodiversity as well 


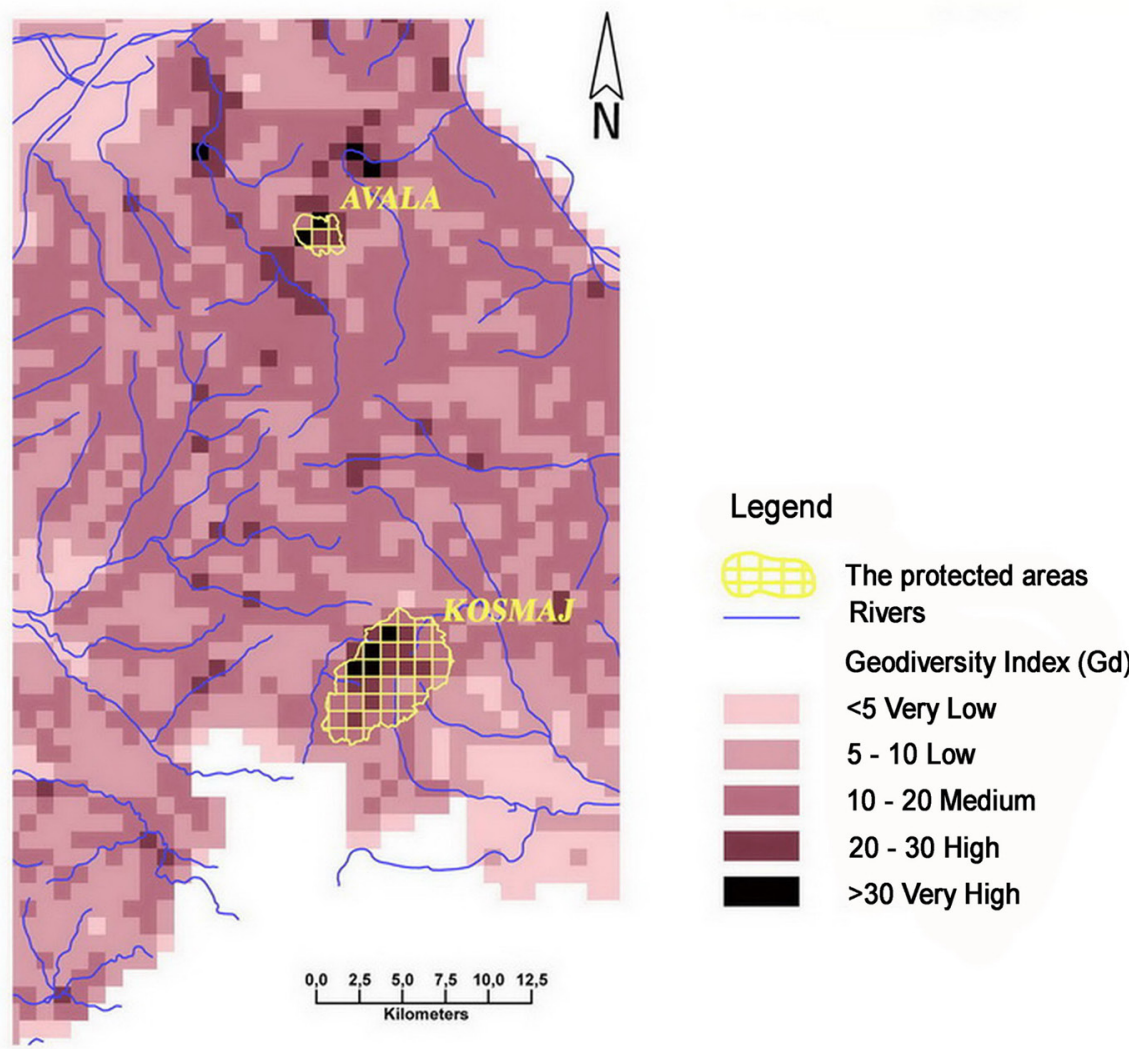

Figure 9. Two of the largest protected areas (Avala and Kosmaj Mts.) with a high Gd index. On the map smaller protected areas as well as protected sites are not displayed.

as environmental changes and the disruption of the entire landscape. As a result of the plant's operation, ash deposits were produced at the thermal power plant „Nikola Tesla“ A and B in Obrenovac, which occupy an area of approximately 800 ha. They have negative effects on human health and degrade the overall geological diversity and the entire ecosystem of Belgrade (GALLAGHER et al., 2008; DE KIMPE \& MOREL, 2000; IVANOVIĆ et al., 1997). In Belgrade, there are no raw metal mines and the older mines in the Avala and Kosmaj Mountains are no longer active. The number of excavations of non-metallic materials, and to a lesser extent, excavations of sand and gravel in the alluvial plains of major rivers, quarries, excavation of clay have been reduced. Other threats to the geodiversity of Belgrade are: torrential flows, flooding the bottom of the riverbed, water erosion, landslides, river channeling, traffic which causes pollution of the air, water and land, construction of buildings and infrastructure systems, industry, changing land use, formation of ash deposits from thermal power plants, ore exploitation, quarries, gravel, compaction, acidification and salinization of soil, reduction of organic matter, climate change and loss of organic matter in soils, disposal of communal and industrial waste. The vulnerability is increased as elements are older or if they are built in softer rocks, or if they are vulnerable to natural and anthropogenic processes.

\section{CONCLUSION}

It is not possible to provide most of the data and information on geodiversity using only the basic geological, geomorphological, hydrological and soil maps. It is necessary to make a geodiversity map, which would serve as a basis for creating strategies for planning and management. The results showed that the quantitative evaluation of geodiversity provides essential data relating to the natural values of an area. Choosing an aspect in which the work assessment and detail of spatial information depends on the size of the territory and purposes. The paper applied the grid-based system (pixel size is $1000 \times 1000 \mathrm{~m}$ ) using a data scale of 1:50.000 to 1:300.000. Making assessments at this scale allowed illustration of the areas of the richest geodiversity. It also serves as a guideline for the direction of the future spatial development of the city, primarily in order to protect the natural values of the city of Belgrade. The highest index values of geodiversity can be an indicator of which areas should be protected (i.e. the valley of the Topčider River and the valley of Vrčin River). Assessment at this scale is not suitable for the protection of individual phenomena. It can be an indicator of where the significant objects of geoheritage are, but to study individual geosites it is necessary to conduct an analysis of large-scale data with a sufficient degree of detail. The assessment of geodiversity is essential in geoconservation activities. Also, the results showed that the areas with the highest values of Gd have the potential for geoconservation, but that these are not the areas that are densely populated (i.e. the mountains of Avala and Kosmaj). The highest population density is in the areas where the values of Gd are medium and low. It is interesting that the areas with small Gd have great significance for the development of the city (i.e. the Pannonian Basin domain). Although these areas are less populated and with less variety of geodiversity, they are the most important agricultural areas. Therefore, the sustainable use of geodiversity should be approached from the aspect of importance for the development of the city in both economic and social terms.

\section{ACKNOWLEDGEMENT}

Some parts of this study are supported by the Ministry of Education, Science and Technological Development of the Republic of Serbia (Projects No. 176008, 47007 and 176015). 


\section{REFERENCES}

ALEXANDROWICZ, Z. \& KOZLOWSKI, K. (1999): From selected geosites to geodiversity conservation: Polish example of modern framework.- In: BARETTINO, D., VALLEJO, M. \& GALLEGO, E. (eds): Towards the balanced management and conservation of the geological heritage in the new milenium, Sociedad Geológica de España, Madrid 52-54.

ANDJELKOVIĆ, M. (1989): Geologija šire okoline Beograda 4-Paleogeografija [Geology ofwider Belgrade area 4 - Paleogeography - in Serbian)].-Zavod za regionalnu geologiju i paleontologiju, Beograd.

ANTONOVIĆ, T., BOGDANOVIĆ, M., ŽIVKOVIĆ, Ž., ĆOROVIĆ, R. \& TRIFUNOVIĆ, M. (1978). Zemljište područja Beograda južno od Save i Dunava [The soil of the Belgrade territory, south of the Sava and Danube - in Serbian].- Gradski geodetski zavod, Beograd.

BENITO-CALVO, A., PÉREZ-GONZÁLEZ, A., MAGRI, O. \& MEZA, P (2009): Assessing regional geodiversity: the Iberian Peninsula.- Eart Surf Process Landf, $34 / 10,1433-1445$.

CVETKOVIĆ, Ž., LOGAR, M. \& ROSIĆ, A. (2013): Mineralogy and characterization of sedimentary particles of the aero sediments collected in the vicinity of power plants and the open pit of coal mine: Kolubara (Serbia).- Environmental Science and Pollution Research, 20/5, 3034-3049.

ĆALIĆ, J., GAUDENYI, T., MILOŠEVIĆ, M.V., ŠTRBAC, D. \& MILIVOJEVIĆ, M. (2012a): Geomorphometrical method for delineation of plains - case study of the south-eastern (Serbian) segment of the Pannonian plain.- Carpathian Journal of Earth and Environmental Sciences, 7/2, 239-248.

ĆALIĆ, J., MILOŠEVIĆ, M.V., GAUDENYI, T., ŠTRBAC, D. \& MILIVOJEVIĆ, M. (2012b): Panonska nizija kao morfostrukturna jedinica Srbije [The Pannonian Plain as Morphostructural unit of Serbia- in Serbian].- Glasnik srpskog geografskog društva, Sveska XCII/1, 47-62.

DAVIDSON, C.M., URQUHART, G.J., BIASIOLI, M., DUARTE, A.D., DIAZ-BARRIENTOS, E., GRCMAN, H., HOSSACK, L., HURSTHOUSE, A.S., MADRID, L.S. RODRIGUES, S. \& ZUPAN, M. (2006): Fractionation of potentially toxic elements in urban soils from five European cities by means of a harmonised sequential extraction procedure.- Analytica Chimica Acta, 565, 63-72.

DE KIMPE, C.R. \& MOREL, J.L. (2000): Urban soil management, a growing concern.Soil Science, 165, 31-40.

DEDIĆ, M. \& INĐIĆ, D. (1990): Akumulacije u službi rešavanja ekoloških problema područja Beograda [Accumulation in the service of solving the environmental problems of the Belgrade - in Serbian].- In: Ekološki problemi Beograda, Savez društva inžinjera i tehničara Beograda, Beograd, 2, 227-239.

DIMITRIJEVIĆ, M., KARAMATA, S., SIKOŠEK, B. \& VESELINOVIĆ, D. (1975a): Osnovna geološka karta SFRJ 1:100000, list Pančevo L 34-114 [Basic Geological Map of SFRY 1:100000, Pančevo sheet - in Serbian].- Savezni geološki zavod, Beograd.

DIMITRIJEVIĆ, M., KARAMATA, S., SIKOŠEK, B. \& VESELINOVIĆ, D. (1975b): Osnovna geološka karta SFRJ 1:100000. Tumač za list Pančevo L 34-114 [Basic Geological Map of SFRY 1:100000, Geology of the Pančevo sheet - in Serbian].Savezni geološki zavod, Beograd.

DIMITRIJEVIĆ, M., DRAGIĆ, D., KARAMATA, S., PETROVIĆ, B., SIKOŠEK, B., ŠUVAČKI, V. \& VESELINOVIĆ, D. (1985a):Osnovna geološka karta 1:100000, list Beograd L 34-113 [Basic Geological Map of SFRY 1:100000, Geology of the Beograd sheet - in Serbian].- Savezni geološki zavod, Beograd.

DIMITRIJEVIĆ, M., DRAGIĆ, D., KARAMATA, S., PETROVIĆ, B., SIKOŠEK, B., ŠUVAČKI, V. \& VESELINOVIĆ, D. (1985b): Osnovna geološka karta 1:100 000 . Tumač za list Beograd L 34-113 [Basic Geological Map of SFRY 1:100000, Geology of the Beograd sheet - in Serbian].- Savezni geološki zavod, Beograd.

ERHARTIČ, B. \& ZORN, M. (2012): Geodiversity and geomorphosite research in Slovenia. - Geografski vestnik, 84/1, 51-63.

FANNING D, S. \& FANNING, M.C.B. (1989): Soil Morphology, Genesis and Classification.- Wiley, New York, 395 p.

FEDERAL SECRETARIAT FOR NATIONAL DEFENCE \& THE FEDERAL COMMITTEE FOR AGRICULTURE (1988): Karta vodnih objekata 1:50000 listovi Beograd 1,2,3,4; Kragujevac 1,2; Lazarevac 1,2; Smederevo 1,3,4; Zrenjanin 4 [Map of water objects 1:50000 - sheets Beograd 1,2,3,4; Kragujevac 1,2; Lazarevac 1,2; Smederevo 1,3,4 and Zrenjanin 4 - in Serbian].- Savezni sekretarijat za narodnu odbranu \& Federalni komitet za poljopriverdu, Beograd.

FILIPOVIĆ, I., VESELINOVIĆ, M., RAJČEVIĆ, D., BODIĆ, D., PETRONIJEVIĆ, S., RAKIĆ, M., GAGIĆ, N. \& MILIĆEVIĆ, M. (1967): Osnovna geološka karta 1:100000 Vladimirci L 34-124 [Basic Geological Map of SFRY 1:100000, Geology of the Vladimircisheet - in Serbian]. - Zavod za geološka i geofizička istraživanja, Beograd.

FILIPOVIĆ, I., MARKOVIĆ, B., PAVLOVIĆ, Z., RODIN, V. \& MARKOVIĆ, O. (1978): Osnovna geološka karta 1:100000. Tumačza list Gornji Milanovac L34-137 [Basic Geological Map of SFRY 1:100000, Geology of the Gornji Milanovac sheet - in Serbian].- Zavod za geološka i geofizička istraživanja, Beograd.

FILIPOVIĆ, I., RODIN, V., PAVLOVIĆ, Z., MARKOVIĆ, B., MILIĆEVIĆ, M. \& ATIN, B. (1980): Osnovna geološka karta 1:100000, list Obrenovac L 34-125 [Ba- sic Geological Map of SFRY 1:100000, Geology of the Obrenovac sheet - in Serbian].- Zavod za geološka, hidrogeološka, geofizička i geotehnička istraživanja „Geozavod“, Beograd.

FILIPOVIĆ, B. (2003): Mineralne, termalne i termomineralne vode Srbije [Mineral, thermal and thermo-mineral waters of Serbia - in Serbian].- Institut za hidrogeologiju Rudarsko-geološkog fakulteta, Beograd.

FILIPOVIĆ, B., KRUNIĆ, O. \& LAZIĆ, M. (2005):Regionalna hidrogeologija [Regional hydrogeology - in Serbian].- Univerzitet u Beogradu, Rudarsko-geološki fakultet, Beograd.

GALLAGHER, F.J., PECHMANN, I., BOGDEN, J.D., GRABOSKY, J. \& WEIS, P. (2008): Soil metal concentration and vegetative assemblage structure in an urban brownfield.- Environmental Pollution, 153, 351-361.

GOOGLE EARTH 5.0. (2009): Belgrade, Serbia. 34T 465986.61mE, $4942464.02 \mathrm{mN}$, Eye alt 145.98km. Landsat 2013. http://www.google.com/earth/index.html

GRAY, M. (1997): Planning and landform: geomorphological authenticity or incongruity in the countryside?-Area, 29/4, 312-324.

GRAY, J.M.(2004): Geodiversity. Valuing and Conserving Abiotic Nature.- John Wiley \& Sons Ltd, Chichester.

HENGL, T. (2006): Finding the right pixel size.- Computers and Geosciences, 32, 1283-1298.

HJORT, J. \& LOUTO, M. (2010): Geodiversity of high latitude landscapes in northern Finland.- Geomorphol, 115, 109-116.

INSTITUTE OF SOIL RESEARCH (1963): Osnovna pedološka karta Srbije listovi Beograd 1,2,3,4; Arandjelovac 1,2; Obrenovac 2,4; Zrenjanin 3,4; Požarevac 3 [Basic pedological map of Serbia 1:50000 - sheets Beograd 1,2,3,4; Arandjelovac 1,2; Obrenovac 2,4; Zrenjanin 3,4; Požarevac 3 - in Serbian].- Institut za proučavanje zemljišta, Beograd.

IUSS WORKING GROUP WRB (2006): World reference base for soil resources 2006.World Soil Resources Reports, 103, FAO, Rome.

IVANOVIĆ, M., IVANOVIĆ, V. \& STAJEVIĆ, D. (1997): Aerozagađenje prašinom u naseljima ugljenih rudarskih basena [Air pollution by dust in coal mining basein settlements - in Serbian].- XXV Savetovanje sa međunarodnim učešćem "Zaštita vazduha 97", 249-255.

JARMAN, D. (1994): Geomorphological authenticity: the planning contribution.- In STEVENS, C., GORDON, J.E., GREEN, C.P. \& MACKLIN, M.G. (eds): Conservingour landscape.- English Nature, Peterborough, 41-45.

KIERNAN, K. (2013): Nature, severity and persistence of geomorphological damage caused by armed conflict. - Land Degradation \& Development. doi: 10.1002/ldr.2216

KOZLOWSKI, S. (2004): Geodiversity: The concept and scope of geodiversity.- Przeglad Geologiczny, 52, 8/2, 833-837.

MANOSSO, F.C. \& NÓBREGA, M.T. (2015): Calculation of Geodiversity from Landscape Units of the Cadeado Range Region in Paraná, Brazil.- Geoheritage. doi: 10.1007/s12371-015-0152-1

MAROVIĆ, M., TOLJIĆ, M., RUNDIĆ, LJ. \& MILIVOJEVIĆ, J. (2007): Neoalpine Tectonics of Serbia.- Serbian Geological Society, Belgrade.

MELELLI, L. (2014): Geodiversity: a new quantitative index for natural protected areas enhancement.-GeoJournal of Tourism and Geosites, VII, 1, 13, 13103-142, 27-37.

MENKOVIĆ, LJ., KOŠĆAL, M., MIJATOVIĆ, M. \&, ŽIVKOVIĆ, M. (2013): Geomorfološka karta Srbije 1:300000 s tumačem [Geomorphological map of Serbia 1: 300000 with an interpreter - in Serbian].- Ministarstvo rudarstva, prirodnih resursa i prostornog planiranja, Beograd.

MILITARY GEOGRAPHICAL INSTITUTE (1988): Topografska karta 1: 300000 listovi Beograd, Kragujevac [Topographic map 1: 300000 - sheets Beograd and Kragujevac - in Serbian].- Vojnogeografski institut, Beograd.

MILITARY GEOGRAPHICAL INSTITUTE (1989): Topografska karta 1:1000000 [Topographic map 1:1000000 - in Serbian].- Vojnogeograsfki institut, Beograd.

MILOJEVIĆ, N., FILIPOVIĆ, B. \& DIMITRIJEVIĆ, N. (1971). Hidrogeološka rejonizacija teritorije Beograda [Hydrogeological zoning of territory of Belgrade - in Serbian].-Zbornik radova Rudarsko-geološkog fakulteta, 13, Beograd.

MILOJEVIĆ, N., FILIPOVIĆ, B. \& DIMITRIJEVIĆ, N. (1975): Hidrogeologija teritorije grada Beograda sa hidrogeološkom kartom razmere 1:100000 [Hydrogeology of the Belgrade city area with hydrogeological map 1:100000 - in Serbian].Belgrade.

NAZZAL, Y.H., AL-ARIFI, N.S.N., JAFRI, M.K., KISHAWY, H.A., GHREFAT, H., EL-WAHEIDI, M.M., BATAYNEH, A. \& ZUMLOT, T. (2015): Multivariate statistical analysis of urban soil contamination by heavy metals at selected industrial locations in the Greater Toronto area, Canada.-Geologia Croatica, 68/2, 147-159.

PAVLOVIĆ, Z., MARKOVIĆ, B., ATIN, B., DOLIĆ, D., GAGIĆ, N., MARKOVIĆ, O., DIMITRIJEVIĆ, M. \&, VUKOVIĆ, M. (1980): Osnovna geološka karta 1:100000, list Smederevo L 34-126 [Basic Geological Map of SFRY 1:100000, Geology of the Smederevo sheet - in Serbian].-Zavod za geološka, hidrogeološka, geofizička i geotehnička istraživanja ,Geozavod“, Beograd.

PELLITERO, R., GONZÁLEZ-AMUCHASTEGUI, M.J., RUIZ-FLAÑO,P. \& SERRANO, E. (2011): Geodiversity and Geomorphosite Assessment Applied to a Natural Protected Area: the Ebro and Rudron Gorges Natural Park (Spain).- Geoheritage, 3, 163-174. 
PEREIRA, D.I., PEREIRA, P., BRILHA, J. \& SANTOS, L. (2013): Geodiversity assessment of Parana State (Brazil): an innovative approach.- Environmental Management, 52, 541-552.

PRUVOT, C., DOUAY, F., HERVE, F. \& WATERLOT, C. (2006): Heavy metals in soil, crops and grass as a source of human exposure in the former mining areas.- Journal of Soils and Sediments, 6, 215-220.

POPOVIĆ, Z. (1990): Odlike gradske klime Beograda [Characteristics of urban climate in Belgarde.- in Serbian].- In: Ekološki problemi Beograda, Savez društva inžinjera i tehničara Beograda, Beograd, 2, 307-317.

RADIVOJEVIĆ, D., MAGYAR, I., TER BORGH, M. \& RUNDIĆ, LJ. (2014): Lake Pannon - Serbian side of the story.- Proceed. of the XVI Serbian Geological Congress, 54-60, Donji Milanovac, Serbia.

RUBAN, D.(2010): Quantification of geodiversity and its loss.- Proc. Geol. Assoc., 121, $326-333$.

RUNDIĆ, LJ. (2010): Geološki objekti i prirodni fenomeni kao integralni elementi geodiverziteta grada Beograda [The geological structures and natural phenomena as integral elements of geodiversity of the city of Belgrade - in Serbian].-Rudarskogeološki fakultet Univerziteta u Beogradu, Beograd.

RUNDIĆ, LJ., GANIĆ, M., KNEŽEVIĆ, S. \& SOLIMAN, A. (2011): Upper Miocene Pannonian sediments from Belgrade (Serbia): new evidence and paleoenvironmental considerations.- Geologica Carpathica, 62/3, 267-278.

RUNDIĆ, LJ., KNEŽEVIĆ, S. \& RAKIJAŠ, M. (2013): Badenian marine transgression: new evidence from the Vrdnik coal basin (northern Serbia).-Ann. Geol. Pennins. Balk, pol. 74, 9-23.

SCILANDS (2015): The shaded hypsometric maps of Hungary, Slovakia, Slovenia, Croatia, Serbia, Bosnia-Herzegovina, Montenegro.- Available online at: http:// www.scilands.de/

SERRANO, E. \& RUIZ-FLANO, P. (2007):Geodiversity: concept, assessment and territorial aplication. The case of Tiermes-Caracena (Soria).- Boletín de la A.G.E. N. ${ }^{\circ}$ 45-2007, 389-393.
SERRANO, E. \& RUIZ-FLAÑO, P. (2007): Geodiversity. A theoretical and applied concept.- Geogr. Helv., 62, 3, 140-147.

SERRANO, E. \& RUIZ-FLAÑO, P. (2009): Geomorphosites and geodiversity.- In: REYNARD, E., CORATZA, P. \& REGOLINI-BISSIG, G. (eds.): Geomorphosites, 49-61.

SERRANO, E., RUIZ-FLAÑO, P. \& ARROYO, P. (2009): Geodiversity assessment in a rural landscape: Tiermes-Caracena area (Soria, Spain).--Mem. Descr.Carta. Geol. Ital., 86, 171-178.

SILVA, J.P., PEREIRA, D.I., AGUIAR, A.M. \& RODRIGUES, C. (2013): Geodiversity assessment of the Xingu drainage basin.- Journal of Maps. doi: 10.1080/ 17445647.2013.775085

SILVA, J.P., RODRIGUES, C. \& PEREIRA, D.I. (2014): Mapping and Analysis of Geodiversity Indices in the Xingu River Basin, Amazonia, Brazil.- Geoheritage. doi: 10.1007/s12371-014-0134-8

STEPIŠNIK, U. \& REPE, B. (2015). Identifikacija vročih točk geodiverzitete na primeru krajinskega parka Rakov Škocjan.- Dela, 44, 45-62. Retrieved from http://revije. ff.uni-lj.si/Dela/article/view/dela.44.1.45-62/5460

TER BORGH, M., VASILIEV, I., STOICA, M., KNEŽEVIĆ, S., MATENCO, L., KRIJGSMAN, W., RUNDIĆ, LJ. \& CLOETHING, S. (2013): The isolation of the Pannonian basin (Central Paratethys): new constraints from magneto- and biostratigraphy.- Global and Planetary Change, 103, 99-118.

USGS (2011): Shuttle Radar Topography Mission (SRTM) 90m Digital Elevation Data, available online at: http://srtm.csi.cgiar.org/

VRANJEŠ, A. (2012): Hidrogeotermalni resursi teritorije grada Beograda [Geothermal resources of the city of Belgrade - in Serbian with an English Abstract].- $\mathrm{PhD}$ Thesis (In Serbian), Faculty of Mining and Geology, University of Belgrade.

VUKMIROVIĆ, D. (2014): 2011 Census of Population, Households and Dwellings in the Republic of Serbia - Population.- Statistical Office of the Republic of Serbia, Belgrade. 